\title{
Determination of Consumer Behaviour amongst Millennials in Dermaceuticals (Skin Care Products)
}

\author{
Abdullah Bin Junaid (Corresponding author) \\ PhD Scholar, Department of Management \\ Faculty of MIT, Jamia Hamdard, New Delhi 110062, India \\ E-mail: abjs07sid@gmail.com \\ Reshma Nasreen \\ Associate Professor, Department of Management \\ Faculty of MIT, Jamia Hamdard, New Delhi 110062, India \\ E-mail: drreshmanasreen2@gmail.com
}

Received: February 18, 2012 Accepted: March 8, 2012 Published: June 1, 2012

doi:10.5539/ijms.v4n3p88 URL: http://dx.doi.org/10.5539/ijms.v4n3p88

\begin{abstract}
Purpose: The chief purpose of the study is to analyze in depth the phenomena of consumer behaviour in buying skin care products amongst millennials in Delhi.

Design/methodology: A questionnaire was developed and distributed to Delhi consumers aged 20 years to 35 years (Millennials) by using Quota sampling technique. A total of 156 completed questionnaires were returned and analysed by using correlation analysis and chi square test in SPSS version 16 . The sample size of 156 includes male and female as well a working and non working people.

Findings: The study aimed to study the behaviour of millennials in India with respect to dermaceuticals. The major finding is the common behaviour exhibited by both the sexes in this age group. Except for difference in under eye cream, the other categories can have common marketing strategies.

Research limitations: The research survey is done in Delhi. Millennials have been chosen for the research which falls under the age group of 20 years to 35 years.

Practical implications: Among the BRIC (Brazil, Russia, India and China) countries India has a sizable "young" population. These "young" representatives contribute to the major chunk of millennials. Thus this study would help companies to strategise effectively for this segment of the market.
\end{abstract}

Originality/value: This work is totally original.

Keywords: Consumer behaviour, Dermaceuticals, Millennials, Anti aging, Anti wrinkle, Skin care

\section{Introduction}

In this new era of globalization, improvement in science, economy, society, education, economy and improved technology gives people a chance to have better life style and living standards. Development in the purchasing power of consumer and the new emerging market trends made people more aware and more conscious towards hygiene and beauty (Souiden \& Diagne, 2009). This development in technology and people awareness leads to rapid growth of beauty care industry, particularly in the last ten years. Since the beauty market is unsaturated and highly profitable, domestic companies were not the only one who was taking advantage in their local market but multinationals companies are also trying to reach and grasp this market. The beauty care market has high competition even then companies were investing into this market so as to full fill the high demand from the customers. The new generation pay more attention towards their look's and health. The global world we are living in sets stereotypes that become role models. In daily life models were widely spread such as on the television, in the commercials, in the magazines, on the billboard, in the fashion shows, in the streets and even at school or at workplace. Now a day role models play an important role, since we can't ignore the fact that most 
people want to look like their role models. For both men and women, a smooth and bright skin with an ideal body shape is an idea to live a wonderful life (Nair et al, 2007).

The desire of customers for the beauty products is growing and this can be observed as the gold mine for this particular market. Using beauty products means psychologically that customers are aware of their conditions and take care of their health, hygiene as well as beauty. The women beauty care industry was growing since a long time but the men grooming market is the new emerging market. Now a day men are more conscious about their looks and demand for new beauty products specially created for men's skin that will drag far ahead from the opinion of older generation about "only sanitation". Consumption of male cosmetic products is more or less affected by the sudden increase in male press. This results in an increase in men's attention towards their beauty products that are launched into the market and claim for improved appearance. Though men have been buying more skin care products to groom themselves, it was predicted that the influence to buy these products upto approximately 80 percent was brought up by their wife or companions (Data panel, 2002). Therefore, it is important to know the impact of different factors on decision making while buying a skin care product. This can be understood by comparing and contrasting the men cosmetic market and women cosmetic market. They have different characteristics and hence companies have to study in depth the different marketing strategies so as to be more responsive to the opening of a new business opportunity as well as added dynamics in the existing situation.

\section{Definitions of Terms}

\subsection{Millennials}

Millennials are a generation of children born between the years 1982 and approximately 2002 (Howe \& Strauss, 2000, p. 41). According to Strauss and Howe millennials are different from any of the other generation. They are " abundant in number, well off, well qualified, and more ethnically diverse than the ones before, they have started to display such positive social habits that earlier generation never associated with the youth, including focussed teamwork, achievement, humility, and good demeanour" (2006, p. 26). Generally, they are conservative towards political issues but are more tolerant towards the changing social scenario than their previous generations. They behave as team players who act cooperatively. They are enduring and conforming, prefer to emphasize on deeds over words and hence works towards overall development of the group. They are socially more active and use technology to enhance the same. On the flip side, Millennials are usually worried over their tight schedules, and require steady motivation. The feelings of exclusivity and being out of the ordinary constitute main characteristics of the millennials. Millennials are considered to be demanding as they are more selective, personalized and customized in the choices they make towards their products and services (Sweeney, 2006).

\subsection{Millennial Behaviours}

Millennial behave in a number of different ways which are statistically important and have an impact on society (Sweeney, 2006). The behaviour and preferences of millennials creates the difference among them and earlier generations at the same age and this seems to be a part of their lifelong culture (Sweeney, 2006). Millennials look ahead for a range of product and services since they have grown up with a huge number of choices and the thought that such plenty of choices is their birthright. Millennials are less traditional in their consumer choices to the other generations. They wish to have full control over what they want, how and when they want it. There are many other characteristics that differentiate millennials from other generations. For example, they are direct, often to the point of appearing rude. Millennials are very confident, possibly because their parents frequently told them that they would be successful in whatsoever they do. Millennials have friends more often from of a different society than themselves and as a result they have more acceptances for cultural difference (Sweeney, 2006).

\subsection{Grooming}

Grooming is somewhat a subjective term, and the meaning varies at different point of time. Commonly, even if the connotation is that one's personal hygiene practices as freely traditional to the customary cultural norm (Waters, 2002). To have same understanding, the word 'Men's grooming products' covers five different categories of products such as bath Products, deodorant, hair care; shampoo, conditioner/treatments, styling products, hair color and others, shaving products; shave cream, lotions/balms, disposable razors/shavers, manual shavers, electric shavers, others and skincare products (MarketResearch.com, 2009). 


\subsection{Skin Care}

Providing maintenance and treatment to the skin under optimal hygienic conditions and comfort for or attending to someone or something; "no medical care is included". Washing, cleansing, bathing, and the use of soaps, detergents, oils, etc falls under the category of effective skin care. In certain conditions like recovering from infection, in case of new born etc taking care of skin is significant (Draelos \& Thaman, 2006).

\subsection{Skin Care Market}

The skin care market is valued at $\$ 180$ million in India (source). The Indian skin care market is shining due to the use of safe and effective procedures, progress in medical technology and increase in awareness. Skin care market is categorised into toners, cleansers, sunscreens, anti-wrinkle creams, dark circle removing creams, astringents, facial creams, moisturizers, fairness creams, day and night creams, etc. Facial creams, moisturizers, fairness creams, day and night creams, etc. are among the most popular products which account for approximately $60 \%$ of this market. Indian skin market is on its initial stage. There is low penetration level in urban as well as rural market in India. Traditional and homemade products are still preferred by the Indians so as to get rid of their skin care problems. With varying life styles, rise in disposable incomes, greater product choice and availability, and greater television influence, more people showing interest in personal grooming. There is a stiff competition among the products to get a better position in the market. Facial skin care products constitute an essential part of the beauty market. In an effort to remove the pimples and the acne, fight stress and worry lines, and to remain young, creams and potions are applied in India as well just like the western countries.. The growth is likely to be around $25 \%$ over the next five years as the penetration level is still low in Indian market. Some of the major players in this segment are Hindustan Lever (Fair \& Lovely, Lakme, Ponds) with a market share of 53\%, followed by CavinKare- Fairever with a market share of over $12 \%$ and Godrej-Fair Glow with a market share of $3.4 \%$. The other players that have a presence in the market are Emami (Gold Turmeric and Naturally Fair), Revlon (Fair \& Glow).

\subsection{Consumer Behaviour}

Consumer behaviour can be defined as the decision-making process and physical activity involved in acquiring, evaluating, using and disposing of goods and services (Consumer Behavior - Issues and concepts). By this definition we can say that buying of good/services is not the only thing that creates attention in consumer behaviour but the process has started earlier than the goods have been acquired or bought. In the consumers mind the buying process starts leading to the search of alternatives among products and those can be perceived with their corns and proms. This process gives rise to internal and external research. The next step appears to be the decision making process step for purchasing and using of goods, them finally comes the post purchase behaviour which is equally important since it provides some clues to the companies regarding the success of the product. Consumer behaviour is a complex, dynamic, multidimensional process, and all marketing decisions are based on assumptions about consumer behaviour.

\section{Regulatory Bodies}

From In the e- book named Cosmeceuticals: Drugs vs. Cosmetics (Elsner, 2000) found in the Ebrary database, regulations governing drugs and cosmetics in different countries has been dealt with. For example pre market requirement notification of the product is not required in EU where as it is mandatory in Japan and Canada however it is voluntary in US and India (RPA Report, 2004, Page 39 and 40). The Cosmetic regulatory authority of India is CDSCO (Central Drugs Standard Control Organization), of EU is EMEA (European Medicine Agency) and of US is FDA (Food and Drug Administration). The Acts governing the cosmetic regulations in different countries are as follows:

1) Drug and Cosmetic Act 1940- India.

2) Food, Drug and Cosmetic Act-USA.

3) Council Directives 76/768/EEC-EU.

\section{Opportunities in the Global Market}

The skin care market seems to be shiny, accessible and profitable. Since new trends and technologies are coming into the cosmetic market, this market is said to be an emerging market. For example, according to MarketResearch.com (2007) more of men are consuming Clarins's products as compared to women. Christian Courtin (2003) from Clarins states that purchasing power of men is greater than what company aimed. She also said that by an average men purchase twice more than that of women. Though men's purchasing power and demand are strong this market seems to be not in a good balance without proper motivation and attraction towards these skin care products. As Jeff Falk mentioned in GCI magazine (2009) that, "Women are more 
emotional in terms of their product purchasing habits, whereas men are drawn to technical, functional things". Because of this reason most of the companies are specialized in the women's beauty care product, however they also attempts to offers products for men cosmetic market to get profit from this particular market as well. This entry into the men market is done to fulfil the demand and also to maintain them into cosmetic market competition. However there are many brands still getting advantage as they were providing products to the women market from the reputation and beauty care specialist image. Men's press is the most powerful medium of communication to influence men to buy these skin care cosmetic products. This focuses on the men's issues related to their skin care problems and how they can overcome these problems. It can emphasize on men's desire. Whether it could be Maximal, Men's Health, New look, or even Mr. Magazine, and so, they all creates and attraction of men's mind towards skin care products (Feng, 2008).

\section{Men's Skin Care Market Forecast}

The men skin care market is blooming and seems to be continuously growing in the upcoming years. According to the beauty care experts the growth of this emerging market is not a trend but this attractive market have a high potential to grow up more and more (Euromonitor, 2007). Beauty care experts assumes that within a period of approximately five years, men's beauty care market will reach 15 percent of the women's beauty care market (Courtin, 2003). As a the long term forecasts, L'Oréal France realizes that in upcoming 50 years, the volume of those men who were using beauty care cream and lotion will reach $50 \%$ that is one in every two men, as of now it is only $21 \%$ comparing to that of $4 \%$ of men in 1994 who uses facial care products. According to Euromonitor (2007) the men's grooming market especially within the skin care sector is among few of the growing market and recorded a 6 percent growth during 2007-2008. The men's grooming market in 2008 is of worth $\$ 26$ billion worldwide which is $8 \%$ of the whole global cosmetics and toiletries market, and this market is further estimated to increase. According to MarketResearch.com (2009), by the year 2014 this segment is supposed to reach $\$ 84.9$ Billion. In addition to this, the specific Men's grooming products such as bath and shower, hair care, shaving cream, lotion, moisturizer, cream, etc, are valued at $\$ 19.7$ Billion worldwide in 2009, and it is expected to be $\$ 28.0$ billion by 2014. It was shown that there is an increase in this market and this could be due to several reasons. The increase in demand from men's beauty care products could be due to new generation's behavior or due to millennials behaviour that would have more feminine characteristic. Because of these reasons cosmetic companies now a day producing cosmetic products specially designed for men's skin and hence men customers have more alternatives to choose these days.

\section{Opportunities in Indian Market}

The Indian skincare market is likely to grow at CAGR of 19\% during 2010-2013, according to RNCOS in its research report. From the past few years the Indian cosmetic industry has recorded strong growth and comes out to be one of the markets with high growth potential in feature. As the lifestyle is changing and customers are becoming more aware they become more conscious towards their look. Among the beauty care industry the skin care segment was found to be the most attractive one. From the last few years the skin care segment recorded an inspiring growth. Due to rise in awareness for personal grooming, the skincare market is further expected to register strong CAGR of nearly $19 \%$ during 2010-2013, as per our research report "Indian Cosmetic Sector Analysis (2009-2012)". This report also suggests that the high sales and fast growth of this segment is due to medical technology advancement with effective and safe procedures and also due to rise in awareness about the benefits of skin care products. The changing climatic condition in India is another reason for high sales of skin care products in India. The Indian cosmetic industry is growing from the past few years and is emerged as one of the potential growth markets for future in skin care segment. In 2010 an impressive sales of Rs 422.3 Billion (US\$ 9.3 Billion) is recorded in cosmetic industry.

These days the cosmetic companies are spending more on promotional activities so as to increase awareness in consumers. According to a new research report by "Indian Cosmetic Sector Analysis (2009-2012)", Indian cosmetics sector will observer remarkable growth in future, due to the awareness both in men and women customers related to beauty concerns. This skin care industry has potential for growth even for existing players as well and new for once. Moreover, the companies have started opting for online retailing and are offering specialized products to generate revenue from all the corners. Rising usage of Cosmeceuticals and Nutricosmetics by the Indian consumers will also pave way for the Indian cosmetics market during the forecast period. Due to the western culture the Indian cosmetic market is not only expanding, but also becoming more sophisticated and complex. Media by its all existing means of communication represents cosmetic products as an important part of day to day life and cannot be avoided and hence in this way media plays a very vital role in the growth of cosmetic industry. The other two main drivers of the Indian cosmetic industry are the rising customer's awareness and affordability. 
India is one of the fastest growing markets, among the Asia Pacific markets. Since the major competitor in the Indian market are Unilever, L'Oreal, Johnson \& Johnson and Emami, this leads to a tough competition for capturing the market. Hence companies need strong and effective marketing plans to stand in this tough competition. For companies to formulate a marketing plan so as to retain in the Indian skin care cosmetic market is a big challenge. Recently, there is a slight slowdown in the cosmetic industry due to destabilized economic status of some developed markets and less penetration of emerging market. However, according to Euromonitor's report (2008) Asian market found out to be the biggest emerging market. The Asia Pacific market's value is up to more than US\$70 billion which is the second highest after the Western European market (Nair and Pillai 2007). Talking about the market, Didier Villanueva, MD, L'Oréal India, says, "The Indian middle class is growing rapidly and so is its demand for the best quality products. Today they want to use the international brands whether they are mass market or premium" (Bhattacharya, 2007).

\section{Research Hypotheses}

Based upon the finding from various researchers, this study is under taken to associate and analyse the dermaceutical products for their relationship with different factors associated with these dermaceutical products in Delhi (India). The different factors associated with usage of these products are: Usage of various skin care product, Reasons for using skin care product, Things that are required in a skin care product and Brand of skin care product. The following hypotheses are verified:

1) $\mathrm{H}_{\text {Null }}$ : There is no relationship between gender and usage of various skin care product.

$\mathrm{H}_{\text {Alternate: }}$ There is a relationship between gender and usage of various skin care product.

2) $\mathrm{H}_{\text {Null }}$ : There is no relationship between age group and reasons for using skin care product (consumer motivation).

$\mathrm{H}_{\text {Alternate: }}$ There is a relationship between age group and reasons for using skin care product.

3) $\mathrm{H}_{\text {Null }}$ : There is no relationship between age group and things that are required in a skin care product (receptiveness to promotional media).

$\mathrm{H}_{\text {Alternate: }}$ There is a relationship between age group and things that are required in a skin care product.

4) $\mathrm{H}_{\text {Null }}$ : There is a relationship between income of a person and the brand of skin care product used by a person.

$\mathrm{H}_{\text {Alternate }}$ : There is a relationship between income of a person and the brand of skin care product used by a person.

\section{Research Methodology}

\subsection{Quantitative Approaches}

A quantitative research is a method based on statistic data's gathering via questionnaires or surveys, in order to know the general public tendency. To answer to the problem, the choice was to collect information about the global market in the first part, concerning the market's history and its facts. The second part is about the consumer behaviour and then the theory about the self concept was developed. To check the theory, a questionnaire has been made, to see what the global tendencies are. As these statistic data have been used, the approach was quantitative. It was relevant to use a concrete survey to illustrate and to compare with the theory. Also, it is interesting to have proper and unique results, rather than use only already done surveys.

\subsection{Type of Research}

The research is exploratory in nature because problem as such is not defined. Consumer survey method was adopted to develop an approach towards the problem so as to understand the consumer behaviour of this population towards dermaceuticals. Closed ended questionnaire was administered through survey approach so as to address the problem exactly.

\subsection{Population and Sample}

Sweeny (2006) has identified people born after 1982 as millennials. This population is in the age group of 29 or less. A conscious decision was taken to understand the behaviour of students and young working professionals. This group includes representatives from both the sexes. Broadly the survey was conducted on students studying in established colleges and universities in South Delhi (India) as well as on working professionals in offices as well as hospitals in the same area. A total of 200 questionnaires was administered out of which 156 usable data has been analysed. Obviously, as the survey is about understanding the relationship between consumer and the cosmetics world, the choice of focusing the questionnaires on both men and women, and more especially on young ones was relevant. People aged between 20 and 35 years old were selected as target audience. They have 
been picked up from the universities and offices. It was quite sure that they used cosmetics whatever they were. It had been chosen to question 156 persons from universities and offices and is both males and females. However, as the research was going on, it has been discovered that this market is developing since few years and is a quite European tendency (Western Europe).

\subsection{Sampling Method}

Non probability quota sampling method is used.

\subsection{Instrument/technique to Collect Data}

\subsubsection{Secondary Data Collection}

Secondary data from researches carried out in various countries as well published reports in magazines, and journals (online as well as printed) have formed the basis of the construct.

\subsubsection{Primary Data Collection}

Here, we collect data ourselves using methods as questionnaires.

\subsubsection{Instrument Used to Analyze the Empirical Data}

To analyse data, the SPSS version 16 software was used. This software is specialized in data's treatment and analysis and realises automatically graphs and results. But the analysis of the results of the questionnaires was developed in the last part of the work.

\section{Findings and Results}

1) By applying correlation analysis we found that out of six skin care product types, there is a relation between three product types with gender and rest of the three product type does not show relationship with the gender. The product types that is Facial forms, Sun creams and Fairness creams shows a positive significance level with gender and hence there is a relationship between these three products with gender. On the other hand, Day and Night moisturizing creams, Anti wrinkle creams and Eye creams does not show a positive significance level with gender hence there is no relation between these products with gender. By applying cross tabulation we found that females are more conscious while using the specific type of skin care product. Hence:

\section{$\boldsymbol{H}_{\text {Null }} \boldsymbol{I}$ is partly accepted as; $\boldsymbol{Z}$ calculated $<Z$ critical $(\alpha=.05)$}

2) By applying correlation analysis we found that there is a significant difference related to reasons for using skin care product with different age group people. By applying cross tabulation we found that 22 years to 26 years age group people uses skin care product for certain reasons. Hence:

$H_{\text {Null }} 2$ is accepted as; $Z$ calculated $>Z$ critical $(\alpha=.05)$

3) By applying correlation analysis we found that there is no significant difference related to receptiveness to promotional media with different age group people. Only celebrity endorsement shows a significance level of correlation with age group (as has been highlighted by the green area in Table 3). By applying cross tabulation we found that 22 years to 26 years age group people feel that celebrity endorsement is required for a specific type of skin care product. Hence:

\section{$H_{\text {Null }} 3$ is accepted as; $Z$ calculated $>Z$ critical $(\alpha=.05)$}

4) By applying correlation analysis we found that there is a significant difference related to Brand consciousness with different income group people. By applying cross tabulation we found that people with income less than 10000 rupees (19.41 US\$) are more brands conscious while using the specific type of skin care product. Hence:

\section{$H_{\text {Null }} 4$ is accepted as; $Z$ calculated $>Z$ critical $(\alpha=.05)$}

5) Table 5 shows that among the total population covered 53.2 percent people are those who are using skin care product from the past more than 16 months.

6) Table 6 shows that 76.3 percent people were spending below 1000 rupees (19.41 US\$) monthly on their skin care products. From here we can conclude that while making the pricing policies for a skin care product to be launched in India the cosmetic companies have to make such product which can cost below this range so as to suite customers spending range.

7) Table 7 shows that the most suitable place for a customer to buy a skin care product is cosmetic counter and general store. Among the total population covered 34 percent people buy skin care products from cosmetic counter and 33.3 percent people prefer general store for purchasing skin care product. 
8) Table 8 shows that 60.3 percent people are comfortable and prefer those cosmetic products which come under a tube packaging. They feel that it was easy to take out the appropriate amount of cosmetic product from the tube in comparison to other type of packaging. They also said that by the tube packaging they can prevent wastage of the product and can use its maximum amount.

9) Table 9 shows that 85.3 percent people feel that they have improved their self image after they start using a skin care product. This shows that this is the perception in the mind of the customers that after using skin care products they can improve their self image.

10) Table 10 shows that 66.7 percent people feel that skin care products are more a women products and 33.3 percent feel that skin care products are not only women products but also men products. The percentage of people who feel that skin care products are for both the sexes is one-third which is a sizeable representation. Earlier we have seen that even people's perception is that the skin care products are only meant for women and not for men but the scenario is changing and people feel that these skin care products as much as important for men as they are for women. By keeping this thing in mind many cosmetic companies are coming with new products specially targeting men.

11) Table 11 says that after using a skin care product 37.8 percent people feel themselves as a part of urban fashion while 46. 2 percent sometimes feel themselves as a part of urban fashion. From here we can conclude that people are using skin care products so as to become a part of urban fashion. Urban fashion means that these respondents consider themselves to be trendy, to be abreast with fashion as well as movers to higher strata of the society. This feeling can be used by advertising and marketing wings of these products as the central theme for promotions.

12) Table 12 shows uniqueness in itself. In our study we covered millennials and these millennials fall under the age group of 20 years to 30 years. This figure shows that within the different categories of age group in millennials most prominent age group that is using the skin care products is 22 years to 26 years. So from here we can say that more focused target audience for cosmetic companies can be the age group of 22 years to 26 years.

13) Table 13 shows that 44.9 percent people feel that while applying a skin care product they haven't suffered with any type of problem but still 26.9 percent people say that one major problem associated with a skin care product is stickiness. They said that after applying a skin care product their site of application become very sticky and this is what they don't like. Many of the active ingredients have to be adapted to the moist climate of the Indian subcontinent. This can be an insight for the research team as well as the promotions team, which can use non-stickiness as their USP.

\section{Conclusion}

The study identifies similarities amongst traits in millennials in India and the western world. India being one of the BRIC countries where the young population is sizable can serve as an important market for many companies. The other important dynamics for India is its indigenous herbal and Ayurvedic formulations, which are gaining importance as people are moving from synthetic to herbal products.

\section{References}

ADA Cosmetics. (2009). ADA Cosmetics International Continues to Strengthen its Position in Asia. [Online] Available: http://www.ada-cosmetics.com/ada-media/presse/pl/Press-info_ADA-Formia-en.pdf (October 17, 2011)

Apaolaza-Ibáñez, V., Hartmann, P., Diehl, S., \& Terlutter, R. (2010). Women satisfaction with cosmetic brands: The role of dissatisfaction and hedonic brand benefits. [Online] Available: http://www.academicjournals.org/ajbm/pdf/pdf2011/4Feb/Vanessa\%20et\%20al.pdf (October 24, 2011)

Barry, D. (2002). How to Win Face in the Korean Cosmetics Market. [Online] Available: $\mathrm{http}: / /$ www.trade.gov/exportamerica/SuccessStories/ss_SKorea.pdf (October 22, 2011)

Bhattacharya, P. (2008). India's Cosmetic Market Ready for Big Leap. [Online] Available: http://www.gcimagazine.com/marketstrends/regions/bric/30806969.html (April 22, 2011)

Business insights. (2004). Youth Marketing in Cosmetics and Toiletries. [Online] Available: http://www.globalbusinessinsights.com/content/rbcg0027m.pdf (September 23, 2011)

Consumer Insight Report. (2010). Millennials the Gen - Y Tsunami is here. [Online] Available: http://www.dmwdirect.com/pdfs/millennials.pdf (April 17, 2011) 
Cosmetics in Russia. (2010). Russian perfumery and cosmetics market: analytics and information. [Online] Available: http://www.cosmeticsinrussia.com/includes/media-kit/media-kit.pdf(July 13, 2010)

Dahten, A., \& Gruenwald, J. (2009). Antiaging Ingredients on the Cosmeceutical Market: Innovation Versus Efficacy. [Online] Available: http://www.thefreelibrary.com/Antiaging+ingredients+on+the+cosmeceutical+market:+innovation+versus...-a01 99464843 (April 20, 2011)

DKSH. (2010). Global Market Expansion Services for the Personal Care \& Cosmetics Industry. [Online] Available: http://www.dksh.com/data/docs/download/7361/en/DKSH-BL-PCI-pdf.pdf (October 11, 2011)

Dureja, H. et al. (2005). Cosmeceuticals: An Emerging Concept. [Online] Available: http://medind.nic.in/ibi/t05/i3/ibit05i3p155.pdf (March 12, 2011)

Ethics Resource Center. (2010). Millennials, Gen X and Baby Boomers: Who's Working at Your Company and What Do They Think About Ethics? [Online] Available: http://www.ethics.org/files/u5/Gen-Diff.pdf (July 8, 2010)

Frost.com. (2007). A Bright Future for Vitamin $\mathrm{E}$ in Cosmetic Applications. [Online] Available: http://www.frost.com/prod/servlet/market-insight-top.pag?docid=95822049 (April 23, 2011)

Freedonia.com. (2011). Cosmeceuticals to 2015 - Market Research, Market Share, Market Size, Sales, Demand Forecast, Market Leaders, Company Profiles, Industry Trends. [Online] Available: http://www.freedoniagroup.com/Cosmeceuticals.html (March 8, 2011)

Giving USA Foundation. (2010). Charitable Giving and the Millennial Generation. [Online] Available: http://download.2164.net/PDF-newsletters/Giving\%20USA\%202010\%20spotlight.pdf (April 18, 2011)

Harris, I. (2006). Is Europe Ready For The Millennials? [Online] Available: http://www.thechair.gr/files/forrester-survey-report.pdf (March 16, 2011)

Hellen, L. (2010). Cosmetics Still Beat Nutrition for Skin Benefits, survey. [Online] Available: http://www.nutraingredients.com/Product-Categories/Cosmeceuticals/Cosmetics-still-beat-nutrition-for-skin-ben efits-survey (April 8, 2011).

Insidecosmeceuticals.com. (2007). Capitalizing on the Cosmetic Market. [Online] Available: http://www.insidecosmeceuticals.com/articles/2007/08/capitalizing-on-the-cosmeceutical-market.aspx (April 15, 2011)

Itlia. (2009). The cosmetic sector of India - Profile 2009. [Online] Available: http://italiaindia.com/images/uploads/pdf/cosmetics-sector-2009.pdf (August 30 2011)

Khraim, H. S. (2001). The influence of brand loyalty on cosmetics buying behavior of UAE female consumers, International Journal of Marketing Studies, 3(2), 123-133.

Kaist. (2006). MISSHA: The Cosmetic Revolution - How to Penetrate the Cosmetic Market and Survive. [Online] Available: http://www.business.kaist.ac.kr/upload/paper/2005-001.pdf (July 25, 2011)

Lewis, H. (2007). Future Product Opportunities in Cosmeceuticals: Innovation in food and drinks with beauty benefits. [Online] Available: http://www.globalbusinessinsights.com/content/rbcg0165t.pdf (April 26, 2011)

Li \& Fung Research Centre. (2011). China's cosmetics market. [Online] Available: http://www.lifunggroup.com/eng/knowledge/research/industry_series17.pdf (September 19, 2011)

Lieblei, C. (2008). Cosmetics Industry Avon. [Online] Available: http://www.centaurmaintenancesupplies.com/carla_personal/Carla/mba/Lieblein_SWOT_MMBA6390_001.pdf (October 8, 2011)

Madras Consultancy Group. (2007). Personal Care Sector in India. [Online] Available: http://www.indianindustryprofiles.com/Personalcare\%20Sector\%20in\%20India.pdf (September 29, 2011)

Mansor, N., Ali, DEBM, \& Yaacob, M. R. (2010). Cosmetic Usage in Malaysia: Understanding of the Major Determinants Affecting the Users. Anline] Available: http://www.ijbssnet.com/journals/Vol._1_No._3_December_2010/27.pdf (October 8, 2011)

Meister, J., \& Willyerd, K. (2010). Spolightonladership: The next generation Mentoring Millennials. [Online] Available: http://epowerment.eqmentor.com/docs/Mentoring\%20Millenials.pdf (April 5, 2011)

Myers, S. (2009). Inside Cosmeceutical Market. [Online] Available: http://www.naturalproductsinsider.com/articles/2009/07/inside-the-cosmeceutical-market.aspx (March 27, 2011) 
Nielsen. (2007). Health beauty and personal grooming: a global Nielsen report. [Online] Available: http://pt.nielsen.com/documents/0705_PersonalGrooming.pdf (August 27, 2011)

Noe, H. M. (2004). Cosmetic explode onto Chinese market. [Online] Available: http://www.moodiereport.com/pdf/oct04_china_report3.pdf (August 30, 2011).

Nutraingredients.com. (2002). Strong growth in cosmeceutical market. [Online] Available: http://www.nutraingredients.com/Industry/Strong-growth-in-cosmeceuticals-market (July 11, 2011)

Oblinger, D. (2003). Boomera \& Gen-Xers Millennials understanding the new students. [Online] Available: http://net.educause.edu/ir/library/pdf/erm0342.pdf (March 28, 2011)

Oricha, B. (2011). Cosmeceuticals: A Review. [Online] Available: http://www.academicjournals.org/AJPP/PDF/pdf2010/April/Oricha.pdf (July 10, 2011)

Pew Research Center. (2010). Millennials: A Portrait of Generation Next. [Online] Available: $\mathrm{http} / / / \mathrm{www}$.pewsocialtrends.org/files/2010/10/millennials-confident-connected-open-to-change.pdf (July 22, 2011)

Pinnoc, S. (2011). Toiletry and Cosmetic Industry Guide. [Online] Available: http://www.bl.uk/bipc/pdfs/toiletries\%20_cosmetics_industry_guide.pdf (September 27, 2011)

Pitman, S. (2011). Demand For Cosmetics Set To Outplace Average Industry Growth. [Online] Available: http://www.cosmeticsdesign.com/Product-Categories/Cosmeceuticals (March 26, 2011)

Raines, C. (2002). Managing Millennials. [Online] Available: http://www.hreonline.com/pdfs/ManagingMillennials.pdf (March 27, 2011)

Rose, J., \& Ruegeme, L. (2010). Lancôm. [Online] Available: http://www.theproduct.com/marketing/lancome_notes.pdf (August 9, 2011)

Schwartz, R. (2011). Cosmeceuticals: Overview. [Online] Available: http://emedicine.medscape.com/article/1067778-overview (March 30, 2011)

Shepard, S. (2004). Managing the Millennials. [Online] Available: http://www.shepardcomm.com/managing-millennials-wp.pdf (March 29, 2011)

Sweeney, R. (2006). Millennial Behaviours \& Demographics. [Online] Available: http://www.google.co.in/url?sa=t\&rct=j\&q=who\%20are\%20 millennials\%20pdf\&source=web\&cd=21\&ved=0C BwQFjAAOBQ\&url=http\%3A\%2F\%2Flibrary1.njit.edu\%2Fstafffolders\%2Fsweeney\%2FMillennials\%2FArticl eMillennialBehaviors.doc\&ei=4QKT5HJBMmD4gSNt_CuBg\&usg=AFQjCNEaGFMJ_yjHwMs7TCRtcAK3p8 Y-Eg (July 9, 2011)

Table 1. Correlation between gender and usage of various skin care products

\begin{tabular}{|c|c|c|c|c|c|c|c|c|}
\hline \multicolumn{9}{|c|}{ Correlations } \\
\hline & & Q1a & Q1b & Q1c & Q1d & Q1e & Q1f & Q19 \\
\hline \multirow[t]{2}{*}{ Q1a } & Pearson Correlation & 1 & .079 & $-.210^{* *}$ & $-.262^{* *}$ & $-.359^{* *}$ & -.120 & $-.192^{*}$ \\
\hline & Sig. (2-tailed) & & .326 & .008 & .001 & .000 & .137 & .017 \\
\hline \multirow[t]{2}{*}{ Q1b } & Pearson Correlation & .079 & 1 & -.148 & $-.175^{*}$ & $-.356^{* *}$ & $-.332^{* *}$ & .098 \\
\hline & Sig. (2-tailed) & .326 & & .064 & .029 & .000 & .000 & .222 \\
\hline \multirow[t]{2}{*}{ Q1c } & Pearson Correlation & $-.210^{* *}$ & -.148 & 1 & $-.216^{* *}$ & -.138 & $-.297^{* *}$ & .018 \\
\hline & Sig. (2-tailed) & .008 & .064 & & .007 & .085 & .000 & .826 \\
\hline \multirow[t]{2}{*}{ Q1d } & Pearson Correlation & $-.262^{* *}$ & $-.175^{*}$ & $-.216^{* *}$ & 1 & $-.279^{* *}$ & -.075 & $-.170^{*}$ \\
\hline & Sig. (2-tailed) & .001 & .029 & .007 & & .000 & .350 & .034 \\
\hline \multirow[t]{2}{*}{ Q1e } & Pearson Correlation & $-.359^{* *}$ & $-.356^{* *}$ & -.138 & $-.279^{* *}$ & 1 & -.080 & $.251^{* *}$ \\
\hline & Sig. (2-tailed) & .000 & .000 & .085 & .000 & & .321 & .002 \\
\hline \multirow[t]{2}{*}{ Q1f } & Pearson Correlation & -.120 & $-.332^{* *}$ & $-.297^{* *}$ & -.075 & -.080 & 1 & -.061 \\
\hline & Sig. (2-tailed) & .137 & .000 & .000 & .350 & .321 & & .447 \\
\hline \multirow[t]{2}{*}{ Q19 } & Pearson Correlation & $-.192^{*}$ & .098 & .018 & $-.170^{*}$ & $.251^{* *}$ & -.061 & 1 \\
\hline & Sig. (2-tailed) & .017 & .222 & .826 & .034 & .002 & .447 & \\
\hline
\end{tabular}


Table 2. Correlation between age and the reasons for using skin care products

\begin{tabular}{|l|l|c|c|c|c|c|c|c|}
\hline \multicolumn{9}{|c|}{ Correlations } \\
\hline \multirow{2}{*}{ Q3a } & Q3a & Q3b & Q3c & Q3d & Q3e & Q3f & Q18 \\
\cline { 2 - 9 } & Pearson Correlation & 1 & $.233^{* *}$ & -.075 & -.015 & $-.192^{*}$ & -.030 & .086 \\
\hline \multirow{2}{*}{ Q3b } & Sig. (2-tailed) & & .003 & .353 & .851 & .016 & .711 & .288 \\
\cline { 2 - 9 } & Pearson Correlation & $.233^{* *}$ & 1 & .114 & .036 & -.007 &. .061 & .060 \\
\hline \multirow{2}{*}{ Q3c } & Sig. (2-tailed) & .003 & & .157 & .651 & .931 & .447 & .456 \\
\cline { 2 - 9 } & Pearson Correlation & -.075 & .114 & 1 & .004 & $.338^{* *}$ & .061 & .057 \\
\hline \multirow{2}{*}{ Q3d } & Sig. (2-tailed) & .353 & .157 & & .956 & .000 & .453 & .480 \\
\cline { 2 - 9 } & Pearson Correlation & -.015 & .036 & .004 & 1 & $.380^{* *}$ & .073 & -.034 \\
\hline \multirow{2}{*}{ Q3e } & Sig. (2-tailed) & .851 & .651 & .956 & & .000 & .362 & .676 \\
\cline { 2 - 9 } & Pearson Correlation &. $.192^{*}$ & -.007 & $.338^{* *}$ & $.380^{* *}$ & 1 & $.338^{* *}$ & .003 \\
\hline \multirow{2}{*}{ Q3f } & Sig. (2-tailed) & .016 & .931 & .000 & .000 & & .000 & .969 \\
\cline { 2 - 9 } & Pearson Correlation & -.030 & -.061 & .061 & .073 & $.338^{* *}$ & 1 & .068 \\
\hline \multirow{2}{*}{ Q18 } & Sig. (2-tailed) & .711 & .447 & .453 & .362 & .000 & & .402 \\
\cline { 2 - 9 } & Pearson Correlation & .086 & .060 & .057 & -.034 & .003 & .068 & 1 \\
\hline
\end{tabular}

Table 3. Correlation between age and things that one feels are required in a skin care product

\begin{tabular}{|l|l|c|c|c|c|c|c|c|}
\hline \multicolumn{2}{|c|}{} & Q17a & Q17b & Q17c & Q17d & Q17e & Q17f & Q18 \\
\hline \multirow{2}{*}{ Q17a } & Pearson Correlation & 1 & $.484^{* *}$ & -.010 & -.059 & .046 & $.292^{* *}$ & .110 \\
\cline { 2 - 9 } & Sig. (2-tailed) & & .000 & .901 & .461 & .572 & .000 & .172 \\
\hline \multirow{2}{*}{ Q17b } & Pearson Correlation & $.484^{* *}$ & 1 & $.214^{* *}$ & .059 & -.089 & $.178^{*}$ & .095 \\
\cline { 2 - 9 } & Sig. (2-tailed) & .000 & & .007 & .461 & .271 & .026 & .238 \\
\hline \multirow{2}{*}{ Q17c } & Pearson Correlation & -.010 & $.214^{* *}$ & 1 & $.313^{* *}$ & -.041 & .099 & -.139 \\
\cline { 2 - 10 } & Sig. (2-tailed) & .901 & .007 & & .000 & .609 & .219 & .084 \\
\hline \multirow{2}{*}{ Q17d } & Pearson Correlation & -.059 & .059 & $.313^{* *}$ & 1 & $.315^{* *}$ & .030 & .001 \\
\cline { 2 - 10 } & Sig. (2-tailed) & .461 & .461 & .000 & & .000 & .714 & .991 \\
\hline \multirow{2}{*}{ Q17e } & Pearson Correlation & .046 & -.089 & -.041 & $.315^{* *}$ & 1 & $.228^{* *}$ & .013 \\
\cline { 2 - 9 } & Sig. (2-tailed) & .572 & .271 & .609 & .000 & & .004 & .875 \\
\hline \multirow{2}{*}{ Q17f } & Pearson Correlation & $.292^{* *}$ & $.178^{*}$ & .099 & .030 & $.228^{* *}$ & 1 & $.162^{*}$ \\
\cline { 2 - 9 } & Sig. (2-tailed) & .000 & .026 & .219 & .714 & .004 & & .043 \\
\hline \multirow{2}{*}{ Q18 } & Pearson Correlation & .110 & .095 & -.139 & .001 & .013 & $.162^{*}$ & 1 \\
\cline { 2 - 9 } & Sig. (2-tailed) & .172 & .238 & .084 & .991 & .875 & .043 & \\
\hline
\end{tabular}


Table 4. Correlation between the income of the person and the brand used by the person

\begin{tabular}{|l|l|c|c|c|c|c|c|c|}
\hline \multicolumn{9}{|c|}{ Correlations } \\
\hline \multirow{2}{*}{ Q2a } & Qearson Correlation & 1 & $.164^{*}$ & $-.352^{* *}$ & $-.438^{* *}$ & $-.427^{* *}$ & .022 & -.034 \\
\cline { 2 - 9 } & Sig. (2-tailed) & & .041 & .000 & .000 & .000 & .783 & .676 \\
\hline \multirow{2}{*}{ Q2b } & Pearson Correlation & $.164^{*}$ & 1 & $-.172^{*}$ & $-.282^{* *}$ & $-.359^{* *}$ & $-.341^{* *}$ & .083 \\
\cline { 2 - 9 } & Sig. (2-tailed) & .041 & & .031 & .000 & .000 & .000 & .305 \\
\hline \multirow{2}{*}{ Q2c } & Pearson Correlation & $-.352^{* *}$ & $-.172^{*}$ & 1 & -.020 & -.033 & $-.347^{* *}$ & .152 \\
\cline { 2 - 9 } & Sig. (2-tailed) & .000 & .031 & & .803 & .685 & .000 & .059 \\
\hline \multirow{2}{*}{ Q2d } & Pearson Correlation & $-.438^{* *}$ & $-.282^{* *}$ & -.020 & 1 & -.022 & $-.294^{* *}$ & -.120 \\
\cline { 2 - 9 } & Sig. (2-tailed) & .000 & .000 & .803 & & .783 & .000 & .136 \\
\hline \multirow{2}{*}{ Q2e } & Pearson Correlation & $-.427^{* *}$ & $-.359^{* *}$ & -.033 & -.022 & 1 & -.091 & .084 \\
\cline { 2 - 9 } & Sig. (2-tailed) & .000 & .000 & .685 & .783 & & .260 & .295 \\
\hline \multirow{2}{*}{ Q2f } & Pearson Correlation & .022 & $-.341^{* *}$ & $-.347^{* *}$ & $-.294^{* *}$ & -.091 & 1 & -.133 \\
\cline { 2 - 9 } & Sig. (2-tailed) & .783 & .000 & .000 & .000 & .260 & & .098 \\
\hline \multirow{2}{*}{ Q23 } & Pearson Correlation & -.034 & .083 & .152 & -.120 & .084 & -.133 & 1 \\
\cline { 2 - 9 } & Sig. (2-tailed) & .676 & .305 & .059 & .136 & .295 & .098 & \\
\hline
\end{tabular}

Table 5. Q.7

\begin{tabular}{|l|c|c|}
\hline Variables & Frequency & Percent \\
\hline Less that 1 month & 8 & 5.1 \\
\hline 1 to 4 months & 20 & 12.8 \\
\hline 4 to 8 months & 14 & 9.0 \\
\hline 8 to 12 months & 21 & 13.5 \\
\hline 12 to 16 months & 10 & 6.4 \\
\hline Above 16 months & 83 & 53.2 \\
\hline Total & 156 & 100.0 \\
\hline
\end{tabular}

Table 6. Q.8

\begin{tabular}{|l|c|c|}
\hline Variables & Frequency & Percent \\
\hline Below 1000 & 119 & 76.3 \\
\hline 1000 to 2000 & 30 & 19.2 \\
\hline 2000 to 3000 & 5 & 3.2 \\
\hline 3000 to 4000 & 1 & .6 \\
\hline Above 4000 & 1 & .6 \\
\hline Total & 156 & 100.0 \\
\hline
\end{tabular}

Table 7. Q.9

\begin{tabular}{|l|c|c|}
\hline Variables & Frequency & Percent \\
\hline Cosmetic Counter & 53 & 34.0 \\
\hline General Store & 52 & 33.3 \\
\hline Super Store & 17 & 10.9 \\
\hline Drug Store & 32 & 20.5 \\
\hline Any Other & 2 & 1.3 \\
\hline Total & 156 & 100.0 \\
\hline
\end{tabular}


Table 8. Q.10

\begin{tabular}{|l|c|c|}
\hline Variables & Frequency & Percent \\
\hline Containers & 41 & 26.3 \\
\hline Tubes & 94 & 60.3 \\
\hline Aerosols & 7 & 4.5 \\
\hline Sachet & 8 & 5.1 \\
\hline Foams & 6 & 3.8 \\
\hline Total & 156 & 100.0 \\
\hline
\end{tabular}

Table 9. Q.11

\begin{tabular}{|l|c|c|}
\hline Variables & Frequency & Percent \\
\hline Yes & 133 & 85.3 \\
\hline No & 23 & 14.7 \\
\hline Total & 156 & 100.0 \\
\hline
\end{tabular}

Table 10. Q.12

\begin{tabular}{|l|c|c|}
\hline Variables & Frequency & Percent \\
\hline Yes & 104 & 66.7 \\
\hline No & 52 & 33.3 \\
\hline Total & 156 & 100.0 \\
\hline
\end{tabular}

Table 11. Q.13

\begin{tabular}{|l|c|c|}
\hline Variables & Frequency & Percent \\
\hline Yes & 59 & 37.8 \\
\hline No & 25 & 16.0 \\
\hline Some times & 72 & 46.2 \\
\hline Total & 156 & 100.0 \\
\hline
\end{tabular}

Table 12. Q.18

\begin{tabular}{|l|c|c|}
\hline \multicolumn{1}{|c|}{ Variables } & Frequency & Percent \\
\hline Below 18 Years & 3 & 1.9 \\
\hline 18 to 22 Years & 39 & 25.0 \\
\hline 22 to 26 Years & 72 & 46.2 \\
\hline 26 to 30 Years & 31 & 19.9 \\
\hline Above 30 years & 11 & 7.1 \\
\hline Total & 156 & 100.0 \\
\hline
\end{tabular}

Table 13. Q.14

\begin{tabular}{|l|c|c|}
\hline Variables & Frequency & Percent \\
\hline Stickiness & 42 & 26.9 \\
\hline Rashes & 12 & 7.7 \\
\hline Allergy & 13 & 8.3 \\
\hline Non Uniform Distribution & 19 & 12.2 \\
\hline None & 70 & 44.9 \\
\hline Total & 156 & 100.0 \\
\hline
\end{tabular}

